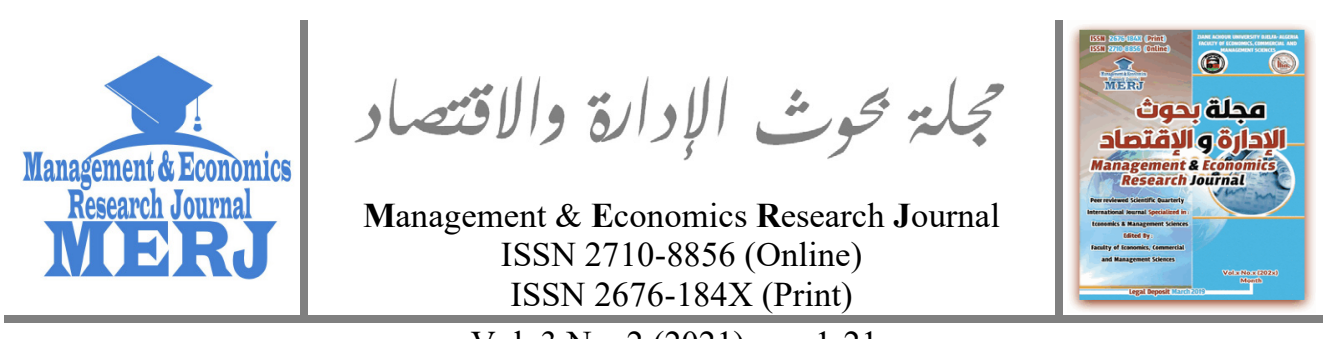

Vol. 3 No. 2 (2021), pp. 1-21

https://doi.org/10.48100/merj.2021.159

Check for updates

\title{
Sectoral Approach in Output Growth Decomposition and its Determinants in Europe
}

\author{
Maja Bacovic 1 (D) \\ ${ }^{1}$ Prof. Dr., University of Montenegro, Faculty of Economics (Montenegro) \\ $\triangle$ majab@ucg.ac.me
}

Received: 10-03-2021

Accepted: 23-04-2021

Published online: 23-04-2021

\section{How to Cite:}

Bacovic, M. (2021). Sectoral Approach in Output Growth Decomposition and its Determinants in Europe. Management \& Economics Research Journal, 3(2), 1-21. https://doi.org/10.48100/merj.2021.159

\section{Abstract:}

The structural changes in Europe have occurred over the last several decades, reducing output share in the goods sector while increasing its share in overall services. Applying the growth accounting approach, we decomposed output growth in the economy while following the sectoral approach, in ten individual sectors in twenty-six European countries, from 2000 to 2019. Our analysis shows that total factor productivity has accounted for nearly half of European countries' growth in production in the past two decades. The other half is mainly attributed to fixed asset growth and employment growth increases, while its variations among sectors are significant. The output growth in the services sector is significantly more driven by employment growth than in the goods sector, leading to overall employment growth in the economy. Applying the panel pooled OLS model, we found that the relevance of expenditures for research and

- Corresponding author: University of Montenegro, Faculty of Economics (Montenegro).

[ $\square$ majab@ucg.ac.me]

(C)2021 the Author(s). This is an open-access article distributed under the terms of (CC BY-NC 4.0) which permits use, distribution and reproduction in any medium, provided the original work is properly cited and is not used for commercial purposes. 
development is high and positive in all sectors but higher in industry and knowledge-intensive services (information and communication, scientific activities) compared to all sectors' average. To the author's best knowledge, this is the first study presenting output growth decomposition estimates at the sectoral level for a selected group of countries, but also the first one giving estimates of TFP in the total economy for a time period chosen. In addition, this is the first study that shows the relevance of investment in research and development at the sectoral level in this specific time period and group of countries. The study's results may be used in defining national policy priorities, as there are various sectors in terms of their impact on employment and economic growth.

Keywords: Output Growth Decomposition, Sectoral Approach, Total Factor Productivity, Research and Development.

JEL Codes: O47, O52.

\section{Introduction}

The structural changes in Europe have occurred over the last several decades, reducing output share in the goods sector while increasing its share in overall services. The sectoral approach in the analysis of economic growth is relevant as its productive structure might determine it. Analysis of the sample of twenty-six European countries in the last two-decade period shows that the average output share in agriculture declined from $2.7 \%$ in 2000 to $2.18 \%$ in 2019 ; in the industry from $21.63 \%$ to $20.27 \%$ respectively; in construction from $6.36 \%$ to $5.4 \%$, while it increased in the overall services sector from $71.1 \%$ to $72.5 \%$. The fastest-growing services sectors are knowledge-intensive, such as information and communication, with output share growth from $3.3 \%$ in 2000 to $6.6 \%$ in 2019 , and professional, scientific and technical activities, from $7.9 \%$ to $10.4 \%$, respectively ${ }^{1}$.

The sectoral perspective in economic analysis is directly linked to structural changes. Kratena (2005) points out that "the shift of resources, output and employment between different sectors accompanying the process of economic growth has been recognised as a possible challenge for adjustment in industrialised economies". Moro (2015) suggested that an economy's growth rate and volatility might be related to its productive structure.

Economic analysis generally accepts that productivity growth is a

${ }^{1}$ Source: Author's calculation based on Eurostat data. 
Management \& Economics Research Journal $\mid$ Vol. 3 No. 2 (2021) $\quad$ pp. 1-21

major source of economic growth and welfare development. As to Margaritis et al. (2005), "labour productivity has accounted for roughly half of the growth in per capita GDP in OECD countries over the last two decades of the XX century, with the other half primarily accounted for by increases in labour utilisation (changes are the demographics, unemployment and labour force participation rates)". Nelson (2000) points out that "in the early 1950 s, empirical work made it clear that growth of total factor productivity accounted for the lion's share of the measured increases in output per worker. Technological advancement has been proposed as a major force behind TFP growth". Further, quoting work by Schmookler (1952), Schultz (1953), Fabricant (1954), Kendrick (1956) and Abramovitz (1956) concluded that "the growth output experienced in the United States after World War II was significantly greater than reasonably can be ascribed to input growth". It was explained by technological advancement, changing labour composition, investments in human capital and reallocation of resources from lower to higher productivity activities and economies of scale.

This research aimed to decompose output growth by applying a growth accounting approach in all sample countries (twenty-six European countries) for the period from 2000 to 2019, at the economic level but also the individual sector level, into the following components: capital growth, labour growth, capacity utilisation growth and TFP growth. This was done to monitor structural changes toward rapid growth in the services sectors in European countries. Therefore, we will be able to investigate whether the expansion of a specific sector is capital, labour or TFP growth driven. In addition, the expansion of scientific and technical knowledge that raises labour productivity and other production inputs has been seen as a source of persistent growth in income per person. Applying a panel-pooled OLS (fixed effects) model, we estimate the significance of the investment in research and development at the sectoral level.

This study uses a sample of twenty-six European countries ${ }^{2}$ from 2000 to 2019. The sample was reduced to twenty-six countries because of data availability. The growth accounting approach was applied to estimate production input growth and total factor productivity (TFP) in the total economy and at the sectoral level for ten sectors: agriculture, forestry and

\footnotetext{
2 Belgium, Czech republic, Denmark, Germany, Estonia, Ireland, Greece, France, Italy, Cyprus, Latvia, Lithuania, Luxemburg, Hungary, Malta, Netherlands, Austria, Poland, Portugal, Romania, Slovenia, Slovakia, Finland, Sweden, Norway United Kingdom.
} 
fishing; industry (except construction); construction; wholesale and retail trade, transport, accommodation and food service activities; financial and insurance activities; information and communication; real estate activities; professional, scientific and technical activities; administrative and support service activities; public administration, defence, education, human health and social work activities; arts, entertainment and recreation; other service activities; activities of the household and extra-territorial organisations and bodies.

Estimating the contribution from inputs and total factor productivity growth is important because of its contribution to long-term income per capita growth. From the methodological computation point of view, since the work of Abramovitz (1956) and Solow (1957), the growth accounting approach has been applied in many studies.

To the author's best knowledge, this is the first study presenting output growth decomposition estimates at the sectoral level for a selected group of countries, but also the first one presenting estimates of TFP in the total economy for a selected time period. In addition, this is the first study that presents the relevance of investment in research and development at the sectoral level in this specific time period and group of countries.

This study is comprised of six sections. This study is comprised of six sections. After the introduction, the second part provides an overview of the research available in the literature. The empirical analysis of structural changes and growth in Europe is covered in the third section. The fourth section discusses the data, the research approach, and the empirical findings. Comparisons of the findings with those from other studies are provided in the fifth section. The final section includes remarks and recommendations for future research are presented.

\section{Literature review}

Due to its relevance, the availability of the literature on sources of growth and structural changes is vast. We list only selections from the most recent, tackling the issues studied in this paper.

There is much evidence in the literature on the importance of total factor productivity (TFP) progress. Barro (1998) points out that technological progress is, in fact, crucial to the long-term per capita growth that the U.S. economy has been able to sustain for two centuries. Based on an extensive literature review, Kim and Loayza (2017) categorised TFP determinants into five components: innovations, education, market efficiency, physical infrastructure and institutional infrastructure. Their research concluded that "variation of TFP across countries for the last three 
\begin{tabular}{l|l||} 
Management \& Economics Research Journal & Vol. 3 No. 2 (2021)
\end{tabular}

pp. $1-21$

decades is explained the most by the physical infrastructure index, followed by the education index and the market efficiency index at a similar level, the innovation index and the institutional infrastructure index".

Romer (2001) stressed that the growth of knowledge is the most important determinant of output growth for the last century. Becker (1993) concluded, "It is clear that all countries which have managed persistent growth in income have also had large increases in the education and training of their labour force. The systematic application of scientific knowledge to the production of goods has greatly increased the value of education, technical schooling, and on-the-job training as the growth of knowledge has been embodied in people - in scientists, scholars, technicians, managers, and other contributors to output".

In their study, Eichler et al. (2006) found that "higher taxes reduce productivity growth, increase innovation resources, and better intercontinental accessibility leads to higher productivity growth". Global trends, industrial structures and spatial spillover effects also influence productivity growth.

Holmes and Schmitz (2010) found that industries experiencing dramatic changes in their competitive environment were forced to increase productivity, or only plants with large productivity gains survive competition increases.

Wu, Guo, and Marinova (2017) presented new evidence on TFP and economic growth in China and found that "productivity growth is the main driver of economic growth in all three sectors: agriculture, manufacturing and services". They also found that technological progress influenced TFP growth significantly.

The availability of literature on structural transformation and its impact on growth is also vast. Morro (2015) studied the impact of the sectoral composition of gross domestic product on cross-country differences in GDP growth and volatility and concluded that "an increase in the share of services in GDP reduces both aggregate total factor productivity (TFP) growth and volatility, thus reducing GDP growth and volatility". FosterMcGregor and Verspagen (2017) presented a study on decomposing TFP growth in manufacturing and services, with a sample of 40 countries and a period from 1995 to 2009 . Their research has shown that "TFP growth in manufacturing tends to outpace that in services in most economies". They found that some exceptions exist, particularly in Asian countries, suggesting that "productivity growth in services need not always be lower than manufacturing". McMillan, Rodrik and Verduzco-Gallo (2014), analysing structural changes in Africa and Latin America, found that labour flows 
from low productivity to high productivity activities are a key driver of development. In addition, since 1990, structural change has been growthreducing, with labour moving from low to high-productive sectors.

Levenko et al. (2019) presented a study on TFP growth accounting in eleven countries from Central and Eastern Europe from 1996-2016. Their study showed that, on average, TFP growth accounted for one-third of GDP growth, while capital deepening accounted for approximately half. The growth accounting methodology was also applied in research by Baier, Dwyer and Tamura (2006), using a sample of 145 countries and data for more than a hundred years for 23 countries in the sample, showing that total factor productivity explains $14 \%$ of average output growth per worker. Total factor productivity means "changes in technology, institutional change, failure of the twin assumption of constant returns to scale and competitive factor markets, and other factors". Bacovic (2021) presented a study on the total factor productivity in middle-income Balkan countries, applying a sectoral approach.

Buera and Kaboski (2012) found a positive relationship between high-skilled labour and the services sector. They developed a theory in which "demand shifts toward more skill-intensive output as productivity rises, increasing the importance of market services relative to home production. Their theory predicts a rising level of skills, skills premium and the relative price of services linked to this skill premium".

\section{The output, employment and labour productivity in Europe - an empirical analysis}

\subsection{Sector's definition, data and sample}

Following NACE classification, sectors are defined as follows: agriculture, forestry and fishing (later agriculture), industry, construction and service sectors disaggregated into seven subsectors: wholesale and retail trade, transport, accommodation and food service activities; financial and insurance activities; information and communication; real estate activities; professional, scientific and technical activities; administrative and support service activities; public administration, defence, education, human health and social work activities; arts, entertainment and recreation; other service activities; activities of the household and extra-territorial organisations and bodies, all data were extracted from the Eurostat database. A detailed 
Management \& Economics Research Journal $\quad$ Vol. 3 No. 2 (2021)

presentation of the indicators used in this research is presented in section 4.1. The analysis was based on a sample of 26 European countries from 2000 to $2019 .{ }^{3}$

\subsection{Dynamics of the structural changes in Europe's output, labour productivity and employment}

Based on annual data on gross value added (output) in all NACE Based on annual data on gross value added (output) in all NACE activities and specific sectors, from a sample of twenty-six European countries, from 2000 to 2019, we estimated the average share of the gross value added (GVA) in specific sectors concerning the economy's gross value added. We observed that industry, trade (including transportation and tourism) and public administration have the largest share in total output, followed by construction and other services (finance, ICT, real estate). Sectors of public administration and trade, followed by industry, are the largest employers, with a higher share of employed in relation to total employment. Labour productivity (measured as output per person employed) is the highest in the finance, information and communications and industry sector (above the total average), while the lowest is in agriculture (Table 1).

Structural changes in Europe have an impact on GDP growth. As in Panel 1, industry growth has the strongest impact on GDP growth, while several services sectors also positively determine it, such as information and communication, trade, finance and professional, scientific and technical services. The growth of the share of public administration in total output has a strong negative impact on GDP growth.

\footnotetext{
${ }^{3}$ All data are available on request.
} 
Table 1. Structure of Europe's output and employment; labour productivity, sample average, 2000-2019

\begin{tabular}{|c|c|c|c|c|}
\hline & \multirow{2}{*}{$\begin{array}{l}\text { Share in total } \\
\text { output } \\
\text { Average } \\
\text { annual } \\
2000-2019\end{array}$} & \multirow{2}{*}{$\begin{array}{l}\text { Share in total } \\
\text { employment } \\
\text { Average } \\
\text { annual } \\
2000-2019\end{array}$} & \multicolumn{2}{|c|}{$\begin{array}{l}\text { Labour productivity } \\
\text { (thousand } 2010 \\
\text { constant euro) }\end{array}$} \\
\hline & & & $\begin{array}{l}\text { Average } \\
\text { annual } \\
2000-2019\end{array}$ & $\begin{array}{l}\text { All }= \\
100\end{array}$ \\
\hline All NACE activities & 100.00 & 100.00 & 45.83 & 1.00 \\
\hline Agriculture, forestry and fishing & 2.42 & 6.62 & 23.39 & 0.51 \\
\hline Industry (except construction) & 20.38 & 17.85 & 57.70 & 1.26 \\
\hline Construction & 6.05 & 7.31 & 36.16 & 0.79 \\
\hline $\begin{array}{l}\text { Wholesale and retail trade, transport, } \\
\text { accommodation and food service activities }\end{array}$ & 20.89 & 24.70 & 37.11 & 0.81 \\
\hline Financial and insurance activities & 5.89 & 2.91 & 91.57 & 2.00 \\
\hline Information and communication & 4.90 & 2.67 & 81.57 & 1.78 \\
\hline Real estate activities & 9.54 & 0.99 & - & - \\
\hline $\begin{array}{l}\text { Professional, scientific and technical activities; } \\
\text { administrative and support service activities }\end{array}$ & 9.16 & 9.87 & 41.91 & 0.91 \\
\hline $\begin{array}{l}\text { Public administration, defence, education, } \\
\text { human health and social work activities }\end{array}$ & 18.01 & 22.32 & 36.66 & 0.80 \\
\hline $\begin{array}{l}\text { Arts, entertainment and recreation; other } \\
\text { service activities; activities of the household } \\
\text { and extra-territorial organisations and bodies }\end{array}$ & 3.12 & 4.77 & 28.70 & 0.63 \\
\hline Observations & 498 & 459 & 459 & 459 \\
\hline
\end{tabular}

Source: Author's calculations, based on Eurostat data (common sample)

- Agriculture, \% output

- Industry, \% output

a Construction, \% output

* Trade at. el, \% output

$\times$ Finance, $\%$ output

+ ICT, $\%$ output

- Real estate, \% output

Profes sional, science at. el, $\%$ output

$\Delta$ Public adminis tration et. al, $\%$ output

$\triangle$ Arts, $\%$ of output

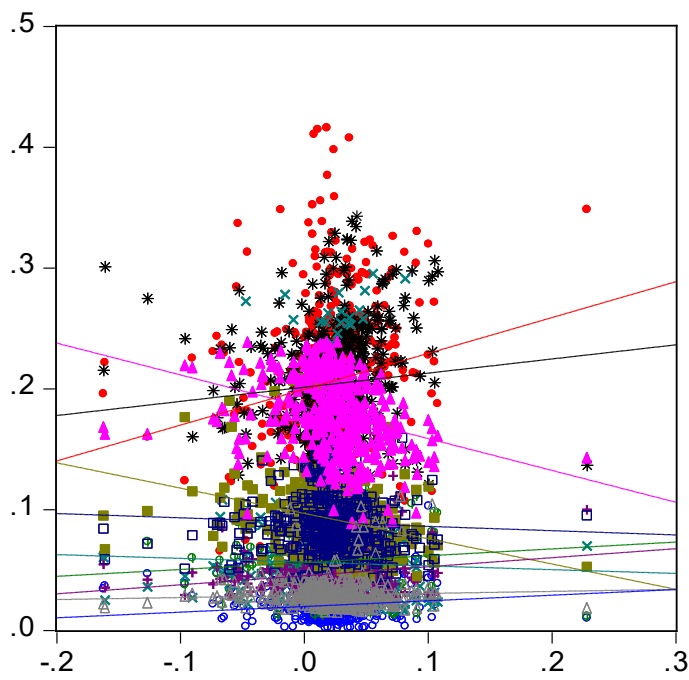

Output growth

Panel 1. Structural changes and output growth, 1920-2019

Source: Author's calculations (based on Eurostat data) 
\begin{tabular}{l|l||l} 
Management \& Economics Research Journal & Vol. 3 No. $2(2021)$ & pp. 1-21
\end{tabular}

Descriptive statistics analysis shows that investigating the sources of output growth on a sectoral level is essential to understand future development trends.

\section{Data, methods and empirical results}

\subsection{Data}

Data used in the research were extracted from the Eurostat database (data on the country's level), with annual frequency. The following indicators were used: gross value added (all NACE activities, chain-linked volumes (2010), million euro), also for individual activities: agriculture, forestry and fishing; industry (except construction); construction; wholesale and retail trade, transport, accommodation and food service activities; financial and insurance activities; information and communication; real estate activities; professional, scientific and technical activities; administrative and support service activities; public administration, defence, education, human health and social work activities; arts, entertainment and recreation; other service activities; activities of the household and extraterritorial organisations and bodies ${ }^{4}$.

Following NACE classification, data on total fixed assets (current replacement costs, million euro) ${ }^{5}$ were adjusted to chain-linked volumes (2010), million euro, applying price index (implicit deflator), 2010=100, euro, for all activities individually. Employment data (total employment domestic concept) were used and classified according to $\mathrm{NACE}^{6}$. Data on expenditures for research and development (originally extracted as a share of GDP) ${ }^{7}$ were adjusted to their nominal values (constant prices, 2010 euro).

\subsection{Methodology - growth accounting approach}

Applying the growth accounting approach, we will decompose

\footnotetext{
${ }^{4}$ National accounts aggregates by industry (up to NACE A*64) [nama_10_a64], extracted on 03/03/2021.

${ }^{5}$ Cross-classification of fixed assets by industry and by asset (stocks) [nama_10_nfa_st], extracted on 04/03/2021.

${ }^{6}$ National accounts employment data by industry (up to NACE A*64) [nama_10_a64_e], extracted on $04 / 03 / 2021$.

${ }^{7}$ Intramural R \& D expenditure (GERD) by sectors of performance [rd_e_gerdtot], extracted on 04/03/2021.
} 
output growth rates in all sectors and ten individual sectors (as listed in section 3.1) into four components: capital stock growth, employment growth, capital utilisation growth and total factor productivity growth.

The growth accounting approach was selected due to its many advantages. "The growth accounting approach provides a complete filing system, in the sense that all phenomena that affect economic growth must do so through input factor quantities, relative factor intensities or total factor productivity growth, either singly or in combination. Second, the growth accounting exercise results may point to areas where parametric studies are likely to be fruitful" (Norsworthy, 2005).

As in Levenko et al. (2019), the starting point is a general specification of aggregate production function:

$Y_{t}=A_{t} F_{t}\left(h_{t} K_{t}, L_{t}\right)$

Where $Y_{t}$ stands for output in the period $t, K_{t}$ is the capital stock in the period $t, h_{t} \in(0,1)$ is the capital utilisation rate in the period $t$; $L_{t}$ is employment, and $A_{t}$ is Total Factor Productivity (TFP).

If the production function is time differenced and perfect competition and constant returns to scale are assumed, the growth rate of output is equal to (Levenko et al., 2019):

$\frac{\Delta \mathrm{Y}_{\mathrm{t}}}{\mathrm{Y}_{\mathrm{t}-1}} \approx\left(1-\alpha_{\mathrm{t}}^{\mathrm{k}}\right) \frac{\Delta \mathrm{L}_{\mathrm{t}}}{\mathrm{L}_{\mathrm{t}-1}}+\alpha_{\mathrm{t}}^{\mathrm{k}} \frac{\Delta \mathrm{K}_{\mathrm{t}}}{\mathrm{K}_{\mathrm{t}-1}}+\alpha_{\mathrm{t}}^{\mathrm{k}} \frac{\Delta \mathrm{h}_{\mathrm{t}}}{\mathrm{h}_{\mathrm{t}-1}}+\frac{\Delta \mathrm{A}_{\mathrm{t}}}{\mathrm{A}_{\mathrm{t}-1}}$

The operator $\Delta$ denotes the first difference, and $\alpha_{t}^{\mathrm{k}}$ is the output elasticity to capital utilized in the period t. equation (2) decomposes output growth into components steaming from growth in employment, available capital, growth in capital utilisation and TFP growth (Levenko et al., 2019).

As in Bacovic (2021), at the sectoral level, the specification of aggregate production function is:

$\mathrm{Y}_{\mathrm{t}, \mathrm{i}}=\mathrm{A}_{\mathrm{t}, \mathrm{i}} \mathrm{F}_{\mathrm{t}, \mathrm{i}}\left(\mathrm{h}_{\mathrm{t}, \mathrm{i}} \mathrm{K}_{\mathrm{t}, \mathrm{i}}, \mathrm{L}_{\mathrm{t}, \mathrm{i}}\right)$

The variable $Y_{t, i}$ is value added (output) in the period $t$ in sector $\mathrm{i}, \mathrm{I}=$ 1, 10(1- agriculture, forestry and fishing; 2- industry except for construction; 3- construction; 4- wholesale and retail trade, transport, accommodation, and food service activities; 5- financial and insurance activities; 6- information and communication; 7- real estate activities; 8professional, scientific and technical activities; administrative and support service activities; 9- public administration, defence, education, human 
\begin{tabular}{l|l|l} 
Management \& Economics Research Journal & Vol. 3 No. 2 (2021) & pp. 1-21
\end{tabular}

health and social work activities; 10- arts, entertainment and recreation; other service activities; activities of the household and extra-territorial organisations and bodies). $\mathrm{K}_{\mathrm{t}, \mathrm{i}}$ is the sector's capital stock (fixed asset) available at the beginning of the period $t$ in sector $i$, while $h_{t, i} \in(0,1)$ is the rate of capital utilisation in the period $t$, so $h_{t} K_{t, i}$ is the capital actually utilised for the production of $Y_{t, i} ; L_{t, i}$ is employment in sector $i$ and $A_{t, i}$ is Total Factor Productivity (TFP) in sector i.

The growth rate of output is equal to:

$\frac{\Delta \mathrm{Y}_{\mathrm{t}, \mathrm{i}}}{\mathrm{Y}_{\mathrm{t}-1, \mathrm{i}}} \approx\left(1-\alpha_{\mathrm{t}, \mathrm{i}}^{\mathrm{k}}\right) \frac{\Delta \mathrm{L}_{\mathrm{t}, \mathrm{i}}}{\mathrm{L}_{\mathrm{t}-1, \mathrm{i}}}+\alpha_{\mathrm{t}, \mathrm{i}}^{\mathrm{k}} \frac{\Delta \mathrm{K}_{\mathrm{t}, \mathrm{i}}}{\mathrm{K}_{\mathrm{t}-1, \mathrm{i}}}+\alpha_{\mathrm{t}, \mathrm{i}}^{\mathrm{k}} \frac{\Delta \mathrm{h}_{\mathrm{t}, \mathrm{i}}}{\mathrm{h}_{\mathrm{t}-1, \mathrm{i}}}+\frac{\Delta \mathrm{A}_{\mathrm{t}, \mathrm{i}}}{\mathrm{A}_{\mathrm{t}-1, \mathrm{i}}}$

There were data on output, capital stock (total fixed assets), and employment; capital utilisation still needs to be calculated. There are a few options in case of missing data on capital utilisation. Levenko et al. (2019) used capacity utilisation in manufacturing as a proxy for capital utilisation in the entire economy. However, we will follow Solow's approach and use change in the unemployment rate (Solow, 1957) as a unique indicator in estimating TFP on the total economy and sectoral level.

In this research, we applied constant estimates for output to capital elasticity, equal to 0.33 , as suggested as a typical value by Romer (2001), on the total economy and sectoral level, assuming that:

$\alpha_{\mathrm{t}, \mathrm{i}}^{\mathrm{k}}=\alpha_{\mathrm{t}}^{\mathrm{k}}$

\subsection{Model, panel pooled OLS (simple and fixed effects)}

We may express the aggregate production of an economy as a function of capital stock, labour and TFP:

$Y_{t}=A_{t} K_{t}^{\alpha} L_{t}^{\beta}, 0<\alpha+\beta<1$

Where $Y_{t}$ represents the economy's aggregate production at the time $\mathrm{t}, \mathrm{A}_{\mathrm{t}}$ is the total factor productivity, and $\mathrm{K}_{\mathrm{t}}$ and $\mathrm{L}_{\mathrm{t}}$ represent the capital stock and labour, respectively. The constants $\alpha$ and $\beta$ represent capital and labour share in income.

Further, we will express TFP as a function of investment in research and development $\mathrm{R}_{\mathrm{t}}$ and other exogenous factors $\mathrm{C}_{\mathrm{t}}$ :

$A_{t}=f\left(R_{t}, C_{t}\right)=R_{t}^{9} C_{t}$ 
After combining equations 6 and 7, we express the production function as:

$\mathrm{Y}_{\mathrm{t}}=\mathrm{C}_{\mathrm{t}} \mathrm{K}_{\mathrm{t}}^{\alpha} \mathrm{L}_{\mathrm{t}}^{\beta} \mathrm{R}_{\mathrm{t}}^{\mathrm{g}}$

Where $\alpha, \beta$ and $\varphi$ represent the elasticities of production with respect to the inputs of production: $\mathrm{K}_{\mathrm{t}}, \mathrm{L}_{\mathrm{t}}$ and $\mathrm{R}_{\mathrm{t}}$.

After taking natural logs, the following equation is obtained:

$L Y_{t}=c+\alpha L K_{t}+\delta L L_{t}+\vartheta L R_{t}+\varepsilon_{t}$

Where $\mathrm{c}$ is the intercept, $\alpha, \beta$ and $\varphi$ are constant elasticities and $\varepsilon_{\mathrm{t}}$ is the error term.

\subsection{Empirical results}

\subsubsection{Growth accounting method}

Applying the growth accounting method presented in section 4.2 on a sample of twenty-six European countries from 2000 to 2019, we decomposed output growth rates in all NACE activities and ten individual NACE activities ${ }^{8}$ (Table 2). We estimated the contribution to gross valueadded growth from capital stock growth, employment growth and total factor productivity growth for the total economy and respective services sectors. In this section, we will present the average value for all variables.

Average annual output growth (gross value added) in the overall sample from 2000 to 2019 was $2.27 \%$, fixed asset growth was $1.99 \%$, employment growth was $0.72 \%$, and total factor productivity growth was $1.12 \%{ }^{9}$. Comparative analysis of gross value-added growth in all NACE activities (total economy) and respective sectors show that output growth was higher in relation to all sectors mean in the information and communication sector (IT), professional, scientific and technical activities (PST) and trade, transport and accommodation (TTA), while in other sectors was below the average. Fixed asset growth (capital stock growth) was also the highest in those sectors (but also above average in agriculture and industry). At the same time, IT and PST activities generated the highest employment growth. Total factor productivity growth was the largest in the

${ }^{8}$ Nomenclature statistique des activités économiques dans la Communauté européenne

${ }^{9}$ Capacity utilisation growth was $(-0.01 \%)$ in all sectors 
\begin{tabular}{l|l|l} 
Management \& Economics Research Journal & Vol. 3 No. 2 (2021) & pp. 1-21 \\
\hline
\end{tabular}

IT sector, followed by industry, financial, and insurance activities.

Table 2. Output growth decomposition in Europe, 2000-2019

\begin{tabular}{|c|c|c|c|c|}
\hline & $\begin{array}{l}\text { Gross value- } \\
\text { added growth }\end{array}$ & $\begin{array}{l}\text { Fixed asset } \\
\text { growth }\end{array}$ & $\begin{array}{l}\text { Employment } \\
\text { growth }\end{array}$ & $\begin{array}{l}\text { TFP } \\
\text { growth }\end{array}$ \\
\hline All NACE activities & 2.27 & 1.99 & 0.72 & 1.12 \\
\hline Agriculture, forestry and fishing & 0.75 & 2.44 & -2.10 & 1.34 \\
\hline Industry (except construction) & 1.93 & 2.21 & -0.81 & 1.73 \\
\hline Construction & 1.03 & 1.29 & 0.63 & 0.18 \\
\hline $\begin{array}{l}\text { Wholesale and retail trade, } \\
\text { transport, accommodation and } \\
\text { food service activities }\end{array}$ & 2.30 & 2.34 & 1.00 & 0.87 \\
\hline Financial and insurance activities & 2.21 & 0.66 & 0.53 & 1.63 \\
\hline Information and communication & 4.99 & 3.57 & 2.56 & 2.09 \\
\hline Real estate activities & 2.06 & 1.20 & 2.43 & 0.03 \\
\hline $\begin{array}{l}\text { Professional, scientific and } \\
\text { technical activities; } \\
\text { administrative and support } \\
\text { service activities }\end{array}$ & 3.82 & 3.77 & 3.50 & 0.22 \\
\hline $\begin{array}{l}\text { Public administration, defence, } \\
\text { education, human health and } \\
\text { social work activities }\end{array}$ & 1.20 & 1.03 & 1.22 & 0.04 \\
\hline $\begin{array}{l}\text { Arts, entertainment and } \\
\text { recreation; other service activities }\end{array}$ & 1.63 & 1.71 & 1.61 & -0.02 \\
\hline Observations & 399 & 399 & 399 & 399 \\
\hline
\end{tabular}

Source: Author's computation

The decomposition of output growth for the total economy and respective sectors has shown different significance from the production inputs (capital stock, employment and total factor productivity) if applied sectoral approach (Table 3).

Our analysis has shown that total factor productivity determined almost half of the output growth in European countries over the last two decades. Increases in fixed asset growth and employment growth primarily determined the other half. Similar findings were presented by Margaritis et al. (2005), who demonstrated that "increases in labour utilisation (changes in the demographics, unemployment, and labour force participation rates) have accounted for the remaining half of the growth in per capita GDP in OECD countries over the same period". 
Bacovic, M. Sectoral approach in output growth decomposition and its determinants in Europe

Table 3. Share of the source of growth

\begin{tabular}{|c|c|c|c|}
\hline & $\begin{array}{l}\text { Fixed Asset } \\
\text { growth }\end{array}$ & $\begin{array}{l}\text { Employment } \\
\text { growth }\end{array}$ & $\begin{array}{l}\text { TFP } \\
\text { growth }\end{array}$ \\
\hline All NACE activities & 28.90 & 21.20 & 50.00 \\
\hline Agriculture, forestry and fishing & 107.70 & -188.20 & 180.50 \\
\hline Industry (except construction) & 37.90 & -28.00 & 90.20 \\
\hline Construction & 41.00 & 40.70 & 18.20 \\
\hline $\begin{array}{l}\text { Wholesale and retail trade, transport, accommodation } \\
\text { and food service activities }\end{array}$ & 33.60 & 29.22 & 37.20 \\
\hline Financial and insurance activities & 9.80 & 16.10 & 74.00 \\
\hline Information and communication & 23.60 & 34.40 & 42.00 \\
\hline Real estate activities & 19.20 & 78.90 & 1.90 \\
\hline $\begin{array}{l}\text { Professional, scientific and technical activities; } \\
\text { administrative and support service activities }\end{array}$ & 32.60 & 61.50 & 5.90 \\
\hline $\begin{array}{l}\text { Public administration, defence, education, human health } \\
\text { and social work activities }\end{array}$ & 28.30 & 67.90 & 3.80 \\
\hline $\begin{array}{l}\text { Arts, entertainment and recreation; other service } \\
\text { activities; activities of the household and extra-territorial } \\
\text { organisations and bodies }\end{array}$ & 34.70 & 66.10 & -0.80 \\
\hline
\end{tabular}

Source: Author's computation

On a sectoral level, contribution to growth varies. In agriculture and industry, employment growth was negative, while it is a significant source of growth in services. Opposite, TFP growth was the most important source of growth in agriculture and industry, but also in financial and insurance activities. Capital growth was the most relevant source of growth in agriculture but contributed less to the services sector growth.

\subsubsection{Panel pooled OLS (simple and fixed effects) model}

The properties of the variables (defined in section 4.1) were examined by determining the existence of unit roots. The Hausman test is used to choose between the fixed-effects model and the random-effects model in panel data.

Estimation results of Equation 9 (Table 4) show that growth in the capital stock (total fixed asset) by one unit leads to output growth of 0.21 , while the same employment growth rate leads to output growth of 0.84 . An increase in expenditures for research and development by one percentage point determines output growth by 0.05 points. Growth in exogenous components of TFP is $0.9 \%$. The result obtained corresponds to the one estimated by applying the growth accounting approach presented in the previous section. 
\begin{tabular}{l|l|l} 
Management \& Economics Research Journal & Vol. 3 No. 2 (2021) & pp. 1-21
\end{tabular}

Table 4. Estimation results (equation 9), panel fixed effects OLS

Dependent variable: $\mathrm{LY}_{\mathrm{t}}$

Sample (adjusted): 20012019

Cross-sections included: 26

Total panel (balanced) observations: 468

\begin{tabular}{lll}
\hline Variable & Coefficient & Std. Error \\
$\mathrm{LK}_{\mathrm{t}}$ & $0.212717^{* * *}$ & 0.036243 \\
$\mathrm{LL}_{\mathrm{t}}$ & $0.842992 * * *$ & 0.062394 \\
$\mathrm{LR}_{\mathrm{t}}$ & $0.058221 * * *$ & 0.012915 \\
$\mathrm{C}$ & $0.009205 * * *$ & 0.001382 \\
\hline
\end{tabular}

$* * * \mathrm{p}<0.01, * * \mathrm{p}<0.05, * \mathrm{p}<0.1$

Source: Author's estimations

Estimating Equation 9 at the industry level shows that the impact from expenditures for research and development is higher in the industry sector compared to the total economy (0.08), the exogenous component of TFP growth also $(1.29 \%)^{10}$, as presented in Table 5.

Table 5. Estimation results (equation 9), applied in the industry sector (panel pooled OLS)

Dependent variable: LY industry,t

Sample (adjusted): 20012019

Cross-sections included: 24

Total panel (balanced) observations: 424

\begin{tabular}{lll}
\hline Variable & Coefficient & Std. Error \\
$\mathrm{LK}_{\text {industry,t }}$ & $0.266830 * * *$ & 0.054682 \\
$\mathrm{LL}_{\text {industry,t }}$ & $0.568351 * * *$ & 0.081894 \\
$\mathrm{LR}_{\mathrm{t}}$ & $0.088898 * *$ & 0.028636 \\
$\mathrm{C}$ & $0.012962 * * *$ & 0.003208 \\
\hline
\end{tabular}

$* * * \mathrm{p}<0.01, * * \mathrm{p}<0.05, * \mathrm{p}<0.1$

Source: Author's estimations

Exogenous components of TFP growth are the highest in the information and communication services sector (3.23\%), which is higher than the value estimated by applying the growth accounting approach, but with a similar trend (information and communication sectors is the one with the highest TFP growth). Contribution from expenditures for research and development is higher in the information and communication sector concerning the total economy, which is expected as this is the knowledgeintensive sector. Results are presented in Table 6.

\footnotetext{
${ }^{10}$ Result obtained corresponds to the one estimated applying growth accounting approach, presented in the previous section.
} 
Table 6. Estimation results (equation 9), applied in the ICT sector (panel fixed effects OLS)

Dependent Variable: LYict,t

Sample (adjusted): 20012019

Cross-sections included: 25

Total panel (balanced) observations: 446

\begin{tabular}{llr}
\hline Variable & Coefficient & Std. Error \\
$\mathrm{LK}_{\text {ict }, \mathrm{t}}$ & $0.339460^{* * *}$ & 0.041459 \\
$\mathrm{LL}_{\mathrm{ict}, \mathrm{t}}$ & $0.104957^{* * *}$ & 0.051201 \\
$\mathrm{LR}_{\mathrm{t}}$ & $0.073761^{* * *}$ & 0.025753 \\
$\mathrm{C}$ & $0.032395^{* * *}$ & 0.003081 \\
\hline${ }^{* * *} \mathrm{p}<0.01,{ }^{* *} \mathrm{p}<0.05,{ }^{*} \mathrm{p}<0.1$ & &
\end{tabular}

Source: Author's estimations

Contribution from expenditures for research and development is the highest in the sector of professional, scientific and technical services, as expected (Table 7). Exogenous components of TFP growth determine output growth in this sector at a slower rate than in the total economy.

Table 7. Estimation results (equation 9), applied in the sector of professional, scientific and technical services (panel fixed effects OLS)

Dependent Variable: $\mathrm{LY}_{\mathrm{pst}, \mathrm{t}}$

Sample (adjusted): 20012019

Cross-sections included: 23

Total panel (balanced) observations: 407

\begin{tabular}{llr}
\hline Variable & Coefficient & Std. Error \\
$\mathrm{LK}_{\mathrm{pst}, \mathrm{t}}$ & $0.252440^{* * *}$ & 0.030831 \\
$\mathrm{LL}_{\mathrm{ipst}, \mathrm{t}} \mathrm{E}$ & $0.423837^{* * *}$ & 0.061037 \\
$\mathrm{LR}_{\mathrm{t}}$ & $0.149740^{* * *}$ & 0.026578 \\
$\mathrm{C}$ & $0.007116^{* *}$ & 0.003480 \\
\hline$* * * \mathrm{p}<0.01, * * \mathrm{p}<0.05, * \mathrm{p}<0.1$ & &
\end{tabular}

Source: Author's estimations

\subsubsection{Comparisons with results with other studies}

Measuring Total factor productivity by applying the growth accounting approach has its difficulties. Fairly innocuous deference in assumptions can lead to very different estimates of TFP growth. (Prem notes, 2000) That is why it is important to emphasise the sensitivity of the results by changing assumptions.

Although earlier research on output growth decomposition applying the growth accounting method does not cover the same sample and time frame, some overlaps make comparison possible. Work done by FosterMcGregor and Verspagen (2017) and Levenko et al. (2019) are the most comparable in terms of a time frame but also methodology and sample 
Management \& Economics Research Journal $\quad$ Vol. 3 No. 2 (2021)

pp. $1-21$

(eighteen countries from our sample match the sample in Foster-McGregor and Verspagen study, while seven countries from our sample match the sample in the study by Levenko et al.).

Despite different methodological approaches and time covered, results from all studies are similar for most countries (Table 8) and show a high degree of consistency. Results from both studies on the sectoral level show higher TFP growth in the industry than in the services sector.

Table 8. Comparisons of the results with the study by Foster-McGregor and Verspagen (2017) and Levenko et.al (2019)

\begin{tabular}{|c|c|c|c|c|}
\hline & \multicolumn{2}{|c|}{ Bacovic (2021) } & \multirow{2}{*}{$\begin{array}{l}\begin{array}{l}\text { Foster-McGregor, } \\
\text { Verspagen (2017) }\end{array} \\
\text { 1995-2009 } \\
\text { cumulative growth }\end{array}$} & \multirow{2}{*}{$\begin{array}{l}\begin{array}{l}\text { Levenko et.al } \\
(2019)\end{array} \\
1996-2016 \\
\text { average annual } \\
\text { growth }\end{array}$} \\
\hline & $\begin{array}{l}2001-2019 \\
\text { average annual } \\
\text { growth }\end{array}$ & $\begin{array}{l}\text { 2001-2019 } \\
\text { cumulative } \\
\text { growth }\end{array}$ & & \\
\hline Belgium & $0.40 \%$ & $7.53 \%$ & $3.96 \%$ & $0.63 \%$ \\
\hline Czechia & $1.88 \%$ & $35.78 \%$ & $23.99 \%$ & \\
\hline Germany & $0.39 \%$ & $7.44 \%$ & $9.19 \%$ & \\
\hline Estonia & $2.04 \%$ & $38.75 \%$ & $34.14 \%$ & $1.77 \%$ \\
\hline Ireland & $1.36 \%$ & $25.78 \%$ & $7.00 \%$ & \\
\hline Greece & $-0.15 \%$ & $-2.93 \%$ & $3.67 \%$ & \\
\hline France & $0.11 \%$ & $2.17 \%$ & $17.94 \%$ & \\
\hline Italy & $-0.48 \%$ & $-9.16 \%$ & $-5.04 \%$ & \\
\hline Lithuania & $3.28 \%$ & $62.28 \%$ & $29.36 \%$ & $1.24 \%$ \\
\hline Luxembourg & $-0.18 \%$ & $-3.40 \%$ & $6.01 \%$ & \\
\hline Hungary & $1.57 \%$ & $29.81 \%$ & $30.20 \%$ & $0.89 \%$ \\
\hline Poland & $2.43 \%$ & $46.16 \%$ & $52.30 \%$ & $1.80 \%$ \\
\hline Slovenia & $1.47 \%$ & $27.92 \%$ & $29.24 \%$ & $1.22 \%$ \\
\hline Slovakia & $2.61 \%$ & $49.61 \%$ & $27.10 \%$ & $0.96 \%$ \\
\hline Finland & $0.07 \%$ & $1.27 \%$ & $19.60 \%$ & \\
\hline $\begin{array}{l}\text { Sweden } \\
\text { United }\end{array}$ & $0.44 \%$ & $8.35 \%$ & $16.98 \%$ & \\
\hline Kingdom & $0.28 \%$ & $5.29 \%$ & $13.13 \%$ & \\
\hline
\end{tabular}

Source: Author's calculations, Foster-McGregor and Verspagen (2017), Levenko et.al (2019)

\section{Conclusion}

The structural changes in Europe have occurred over the last several decades, reducing output share in the goods sector while increasing its stake in overall services. The sectoral perspective in economic analysis is important as an economy's growth rate and volatility might be related to its 
productive structure. Estimating the contribution from inputs and total factor productivity growth at the sectoral level provides valuable insights into the impact of structural changes on overall growth.

Applying the growth accounting approach, we decomposed output growth rates in twenty-six European countries from 2000 to 2019 in all aggregated sectors and ten individual services sectors (agriculture, industry, construction and seven services sectors). Outputs have been divided into four components: capital stock growth, employment growth, capital utilisation growth and total factor productivity growth.

The computation of the share of the source of growth in total growth in the economy and specific sectors has shown that the total factor productivity is the primary source of growth, accounting for $50 \%$ in all sectors but more significant in agriculture and industry. Employment growth is the most crucial source of growth in services. Capital stock growth is most relevant in agriculture, industry and construction.

Applying the panel pooled OLS model, we found that the relevance of expenditures for research and development is high and positive in all sectors but higher in industry and knowledge-intensive services (information and communication, scientific activities) compared to all sectors' average.

Therefore, a sectoral approach to growth analysis is essential, as there is no typical behaviour in all economic sectors. Also, as concluded earlier, services sector growth is the key driving force behind employment growth, as average annual employment growth was even negative in agriculture and industry.

The study's results may be used in defining national policy priorities, as there are various sectors in terms of their impact on employment and economic growth. Further research should focus on explaining what determines structural changes. Variations in wages and income from different sectors may be possible but need further investigation.

\section{Declaration of conflicting interests}

The author(s) declared no potential conflicts of interest with respect to the research, authorship, and/or publication of this article.

\section{References}

Abramovitz, M. (1956). Resource and Output Trends in the United States Since 1870. In M. Abramovitz, Resource and Output Trends in the United States Since 1870, 1-23. NBER. https://doi.org/10.2307/3498218 
\begin{tabular}{l|l||l} 
Management \& Economics Research Journal & Vol. 3 No. $2(2021)$ & pp. 1-21
\end{tabular}

Arratibel, O., Heinz, F., Martin, R., Przybyla, M., Rawdanowicz, L., Serafini, R., \& Zumer, T. (2007). Determinants of growth in the Central and Eastern European EU member states - a production function approach. Frankfurt: European Central bank (ECB Occasional Paper, No. 61).

Bacovic, M. (2021). Total factor productivity growth in upper middle-income Balkan countries from 2000-2017, total economy and sectoral approach: growth accounting method. Argumenta Oeconomica, 1(46) - forthcoming.

Baier, S., Dwyer, G., \& Tamura, R. (2006). How important are capital and total factor productivity for economic growth? Economic Inquiry 44(1), 23-49. https://doi.org/10.1093/ei/cbj003

Becker, S. G. (1993). Human Capital: A Theoretical and Empirical Analysis with Special Reference to Education ( $3^{\text {rd }}$ ed.) 15-28. Chicago: The University of Chicago Press.https://doi.org/10.7208/chicago/9780226041223.001.0001

Buera, F., \& Kaboski, J. (2012). The Rise of the Service Economy. American Economic Review, 102(6), 2540 2569.https://doi.org/10.1257/aer.102.6.2540

Chala, V. (2015). The peculiarities of trade specialization in creative industries in the Central and Eastern European countries. Eastern Journal of European Studies, 6(1), 91-109.

Dombi, A. (2013). Economic Growth and Development in Central and Eastern Europe after the Transformation. Public Finance Quarterly, 58(4), 452468

Eichler, M., Grass, M., Blochliger, H., \& Ott, H. (2006). Determinants of Productivity Growth. Basel: BAK.

Foster-McGregor, N., \& Verspagen, B. (2017). Decomposing Total Factor Productivity Growth in Manufacturing and Services. Asian Development Review, 34(1), 88-115.https://doi.org/10.1162/adev_a_00082

Holmes, T. J., \& Schmitz. , J. A. (2010). Competition and Productivity: A Review of Evidence. Annual Review of Economics, 2, 619-642.

Holtgrewe, U. (2015). Services Research along the Service Process: An overview study to support UNI Europa's. Vienna: Forba.

Kim, Y. E., \& Loayza, N. V. (2017, October 25). Productivity and its Determinants: Innovation, Education, Efficiency, Infrastructure, and Institutions.http://pubdocs.worldbank.org/en/378031511165998244/Produc tivity-and-its-determinants-25-October-2017.pdf

Konan, D. E., \& Maskus, K. (2016). Quantifying the Impact of Services Liberalization in a Developing Country. World Bank Policy Research 
Working Paper, no 3193. https://doi.org/10.1596/1813-9450-3193

Kratena, K. (2005). Sectoral Economy: Do sectors Really Matter? Estudios de Economia Aplicada, 23(2), 289-298.

Krenz, A. (2014). Services sectors concentration and countries specialization patterns in the European Union: A comparative analysis with a special focus on France, Germany, Greece and the UK. Regional and Sectoral Economic Studies, 14(1), 23-32.

Levenko, N., Kaspar, O., \& Karsten, S. (2019). Total factor productivity growth in Central and Eastern Europe before, during and after the global financial crisis. Post-Communist Economies, 31(2), 137-160 https://doi.org/10.1080/14631377.2018.1460713

Margaritis, D., Scrimgeour, F., Cameron, M., \& Tressler, J. (2005). Productivity and Economic Growth in Australia, New Zealand and Ireland. Agenda: A Journal of Policy Analysis and Reform, 12(4), 291-308. https://doi.org/10.22459/ag.12.04.2005.01

Morro, A. (2015). Structural Change, Growth and Volatility. American Economic Journal: Macroeconomics, 7(3), 259-294.

Nelson, R. R. (2000). The Sources of Economic Growth. Cambridge, Massachusetts/London, England: Harvard University Press.

Norsworthy, J. (2005). Growth Accounting and Productivity Measurement. Review of Income and Wealth 30(3), 309-329. https://doi.org/10.1111/j.14754991.1984.tb00554.x

Prem notes. (2000). Measuring growth in total factor productivity. Washington, D.C.: The World bank.

Romer, D. (2001). Advanced Macroeconomics. New York: McGraw-Hill Higher Education.

Solow, M. R. (1957). Technical Change and the Aggregate Production Function. The Review of Economics and Statistics, 39(3), 312-320.

Wu, Y., Guo, X., \& Marinova, D. (2017). Productivity, Innovation and China's Economic Growth. In L. Song, R. Garnaut, C. Fang, \& L. Johnston, China's New Sources of Economic Growth. ANU Press. https://doi.org/10.22459/cnseg.07.2017.09 